\title{
Reproductive toxicity of benzophenone-3
}

\author{
Florian Seidel ${ }^{1}$
}

Received: 4 August 2020 / Accepted: 10 August 2020 / Published online: 12 September 2020

(c) Springer-Verlag GmbH Germany, part of Springer Nature 2020

Recently, Santamaria and colleagues published a dermal exposure study with benzophenone-3 in pregnant mice to study the possible effects on the outcome of the progeny (Santamaria et al. 2020). Benzophenone-3 is one of the most frequently used ultraviolet light filters present in many skincare products (Krause et al. 2012; Darbre and Harvey 2015), which is detectable in the urine of exposed humans (Calafat et al. 2008; Buck Louis et al. 2014; Frederiksen et al. 2013; Zhang et al. 2013). Humans are not only exposed by the dermal application, but also via drinking water and food (Loraine and Pettigrove 2006; Kim and Choi 2014; Hayden et al. 1997; Janjua et al. 2008). The possible reproductive toxicity of benzophenone-3 has been controversially discussed (Ghazipura et al. 2017; Santamaría et al. 2019; Vela-Soria et al. 2014).

The strengths of the present study of Santamaria are the careful selection of a human-relevant dose, the dermal route of application of benzophenone-3, the selection of an interesting window of exposure and internal monitoring of the test compound in serum and amniotic fluid (Santamaria et al. 2020). A dose of $50 \mathrm{mg} / \mathrm{kg}$ body weight/day was chosen, because this corresponds to the calculated dose after controlled whole-body dermal application in humans (Janjua et al. 2008). Mice were dermally exposed during the first 7 days of pregnancy, which corresponds to the first trimester of a human pregnancy. A limitation of the study is that the effects were not studied dose-dependently. Benzophenone3-associated key findings were:

- Reduced fetal weight at gestational day 14 (gd14).

- Reduced feto-placental index of first pregnancy at gd14.

- Reduced offspring weight of the first progeny.

- Reduced placenta weight of the second pregnancy.

Florian Seidel

seidelf@ifado.de

1 Leibniz Research Centre for Working Environment and Human Factors, Ardeystr 67, 44139 Dortmund, Germany
- Higher percentage of females in the first and second progenies of mothers exposed to benzophenone-3

These are interesting results and further studies with a similar experimental design and a predefined research hypothesis should be performed.

Currently, much effort is invested to establish in vitro tests of human developmental toxicity using human stem and precursor cells (Krug et al. 2013; Godoy et al. 2013; 2015; Sachinidis et al. 2019; Leist et al. 2017). Tests systems are available for iPSC-derived cells (Waldmann et al. 2017; Shinde et al. 2016, 2017) and transcriptomics (Balmer et al. 2014; Zimmer et al. 2014; Waldmann et al. 2014) or amino acids (Palmer et al. 2013; Kleinstreuer et al. 2011) have been shown to represent reliable readouts. These systems have been used to differentiate developmental toxicants and controls (Pallocca et al. 2016; Reif 2015) as well as different classes of developmental toxicants (Rempel et al. 2015; Sisnaiske et al. 2014). It will be interesting to learn in future if benzophenone- 3 leads to positive results in these in vitro assays at concentrations relevant in human serum after application of, e.g., sun cream. In conclusion, the present study of Santamaria and colleagues gives evidence that the use of benzophenone- 3 in human skincare products may cause adverse consequences and follow-up studies for clarification of the human relevance of the observation are required.

\section{Compliance with ethical standards}

Conflict of interest The author declares that he has no conflict of interest.

\section{References}

Balmer NV, Klima S, Rempel E et al (2014) From transient transcriptome responses to disturbed neurodevelopment: role of histone acetylation and methylation as epigenetic switch between reversible and 
irreversible drug effects. Arch Toxicol 88(7):1451-1468. https://doi. org/10.1007/s00204-014-1279-6

Buck Louis GM, Kannan K, Sapra KJ et al (2014) Urinary concentrations of benzophenone-type ultraviolet radiation filters and couples' fecundity. Am J Epidemiol 180:1168-1175. https://doi.org/10.1093/ aje/kwu285

Calafat AM, Wong L-Y, Ye X et al (2008) Concentrations of the sunscreen agent benzophenone-3 in residents of the united states: national health and nutrition examination survey 2003-2004. Environ Health Perspect 116:893-897. https://doi.org/10.1289/ehp.11269

Darbre PD, Harvey PW (2015) Regulatory considerations for dermal application of endocrine disrupters in personal care products. In: Darbre PD (ed) Endocrine disruption and human health. Academic Press, Cambridge, pp 343-361

Frederiksen H, Nielsen JK, Mørck TA et al (2013) Urinary excretion of phthalate metabolites, phenols and parabens in rural and urban Danish mother-child pairs. Int J Hyg Environ Health 216:772-783. https://doi.org/10.1016/j.ijheh.2013.02.006

Ghazipura M, McGowan R, Arslan A, Hossain T (2017) Exposure to benzophenone-3 and reproductive toxicity: a systematic review of human and animal studies. Reprod Toxicol 73:175-183. https://doi. org/10.1016/j.reprotox.2017.08.015

Godoy P, Hewitt NJ, Albrecht U et al (2013) Recent advances in 2D and $3 \mathrm{D}$ in vitro systems using primary hepatocytes, alternative hepatocyte sources and non-parenchymal liver cells and their use in investigating mechanisms of hepatotoxicity, cell signaling and ADME. Arch Toxicol 87(8):1315-1530. https://doi.org/10.1007/ s00204-013-1078-5

Godoy P, Schmidt-Heck W, Natarajan K et al (2015) Gene networks and transcription factor motifs defining the differentiation of stem cells into hepatocyte-like cells. J Hepatol 63(4):934-942. https://doi. org/10.1016/j.jhep.2015.05.013

Hayden CG, Roberts MS, Benson HA (1997) Systemic absorption of sunscreen after topical application. The Lancet 350:863-864. https ://doi.org/10.1016/S0140-6736(05)62032-6

Janjua NR, Kongshoj B, Andersson A-M, Wulf HC (2008) Sunscreens in human plasma and urine after repeated whole-body topical application. J Eur Acad Dermatol Venereol 22:456-461. https://doi.org/10. 1111/j.1468-3083.2007.02492.x

Kim S, Choi K (2014) Occurrences, toxicities, and ecological risks of benzophenone-3, a common component of organic sunscreen products: a mini-review. Environ Int 70:143-157. https://doi. org/10.1016/j.envint.2014.05.015

Kleinstreuer NC, Smith AM, West PR et al (2011) Identifying developmental toxicity pathways for a subset of ToxCast chemicals using human embryonic stem cells and metabolomics. Toxicol Appl Pharmacol 257(1):111-121. https://doi.org/10.1016/j.taap.2011.08.025

Krause M, Klit A, Jensen MB et al (2012) Sunscreens: are they beneficial for health? an overview of endocrine disrupting properties of UV-filters. Int J Androl 35:424-436. https://doi.org/10.111 $1 / \mathrm{j} .1365-2605.2012 .01280 . x$

Krug AK, Kolde R, Gaspar JA et al (2013) Human embryonic stem cell-derived test systems for developmental neurotoxicity: a transcriptomics approach. Arch Toxicol 87(1):123-143. https://doi. org/10.1007/s00204-012-0967-3

Leist M, Ghallab A, Graepel R et al (2017) Adverse outcome pathways: opportunities, limitations and open questions. Arch Toxicol 91(11):3477-3505. https://doi.org/10.1007/s00204-017-2045-3

Loraine GA, Pettigrove ME (2006) Seasonal variations in concentrations of pharmaceuticals and personal care products in drinking water and reclaimed wastewater in Southern California. Environ Sci Technol 40:687-695. https://doi.org/10.1021/es051380x

Palmer JA, Smith AM, Egnash LA et al (2013) Establishment and assessment of a new human embryonic stem cell-based biomarker assay for developmental toxicity screening. Birth Defects Res B Dev Reprod Toxicol 98(4):343-363. https://doi.org/10.1002/bdrb.21078
Pallocca G, Grinberg M, Henry M et al (2016) Identification of transcriptome signatures and biomarkers specific for potential developmental toxicants inhibiting human neural crest cell migration. Arch Toxicol 90(1):159-180. https://doi.org/10.1007/s00204-015-1658-7

Reif R (2015) Expression classifiers for developmental toxicants. EXCLI J 14:1291-1293. https://doi.org/10.17179/excli2015-765.eCollectio n2015

Rempel E, Hoelting L, Waldmann T et al (2015) A transcriptome-based classifier to identify developmental toxicants by stem cell testing: design, validation and optimization for histone deacetylase inhibitors. Arch Toxicol 89(9):1599-1618. https://doi.org/10.1007/s0020 4-015-1573-y

Sachinidis A, Albrecht W, Nell P et al (2019) Road map for development of stem cell-based alternative test methods. Trends Mol Med 25(6):470-481. https://doi.org/10.1016/j.molmed.2019.04.003

Santamaría CG, Abud JE, Porporato MM et al (2019) The UV filter benzophenone 3 , alters early follicular assembly in rat whole ovary cultures. Toxicol Lett 303:48-54. https://doi.org/10.1016/j.toxle t.2018.12.016

Santamaria CG, Meyer N, Schumacher A et al (2020) Dermal exposure to the UV filter benzophenone-3 during early pregnancy affects fetal growth and sex ratio of the progeny in mice. Arch Toxicol. https ://doi.org/10.1007/s00204-020-02776-5 (Online ahead of print)

Shinde V, Hoelting L, Srinivasan SP et al (2017) Definition of transcriptome-based indices for quantitative characterization of chemically disturbed stem cell development: introduction of the STOP-Toxukn and STOP-Toxukk tests. Arch Toxicol 91(2):839-864. https://doi. org/10.1007/s00204-016-1741-8

Shinde V, Perumal Srinivasan S, Henry M et al (2016) Comparison of a teratogenic transcriptome-based predictive test based on human embryonic versus inducible pluripotent stem cells. Stem Cell Res Ther 7(1):190. https://doi.org/10.1186/s13287-016-0449-2

Sisnaiske J, Hausherr V, Krug AK et al (2014) Acrylamide alters neurotransmitter induced calcium responses in murine ESC-derived and primary neurons. Neurotoxicology 43:117-126. https://doi. org/10.1016/j.neuro.2014.03.010

Vela-Soria F, Rodríguez I, Ballesteros O et al (2014) Simplified matrix solid phase dispersion procedure for the determination of parabens and benzophenone-ultraviolet filters in human placental tissue samples. J Chromatogr A 1371:39-47. https://doi.org/10.1016/j.chrom a.2014.10.063

Waldmann T, Grinberg M, König A et al (2017) Stem cell transcriptome responses and corresponding biomarkers that indicate the transition from adaptive responses to cytotoxicity. Chem Res Toxicol 30(4):905-922. https://doi.org/10.1021/acs.chemrestox.6b00259

Waldmann T, Rempel E, Balmer NV et al (2014) Design principles of concentration-dependent transcriptome deviations in drug-exposed differentiating stem cells. Chem Res Toxicol 27(3):408-420. https ://doi.org/10.1021/tx400402j

Zhang T, Sun H, Qin X et al (2013) Benzophenone-type UV filters in urine and blood from children, adults, and pregnant women in China: Partitioning between blood and urine as well as maternal and fetal cord blood. Sci Total Environ 461-462:49-55. https://doi. org/10.1016/j.scitotenv.2013.04.074

Zimmer B, Pallocca G, Dreser N et al (2014) Profiling of drugs and environmental chemicals for functional impairment of neural crest migration in a novel stem cell-based test battery. Arch Toxicol 88(5):1109-1126. https://doi.org/10.1007/s00204-014-1231-9

Publisher's Note Springer Nature remains neutral with regard to jurisdictional claims in published maps and institutional affiliations. 